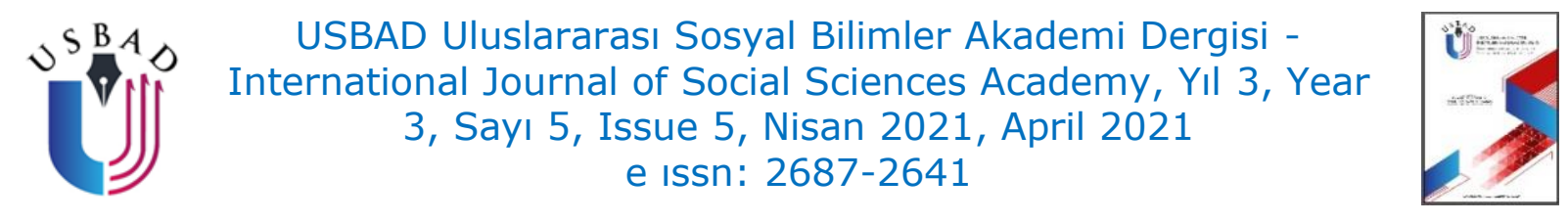

\title{
OSMANLI DEVLETİ'NDE KAPİTÜLASYONLARIN KALDIRILMASI SONRASINDA HALKIN TEPKİLERİNE DÂİR BAZI TESPİTLER
}

\author{
SOME DESTINATIONS ON THE REACTIONS OF THE PEOPLE AFTER THE
} REMOVAL OF CAPITULATIONS IN THE OTTOMAN STATE

\author{
Mustafa Fırat GÜL \\ Dr., Aksaray Belediyesi Azm-i Milli Sanayi ve Bilim Müzesi, \\ Aksaray/Türkiye. \\ Dr., Aksaray Municipality Azm-i Milli Industry and Science Museum, \\ Aksaray/Türkiye. \\ mustafafiratgul@gmail.com
}

ORCID ID: 0000-0001-9023-4131

Makale bilgisi | Article Information

DOI: $10.47994 /$ usbad.885194

Makale Türü / Article Type: Araştırma Makalesi / Research Article

Geliş Tarihi / Date Received: 23.02.2021

Kabul Tarihi / Date Accepted: 14.04.2021

Yayın Tarihi / Date Published: 20.04.2021

Yayın Sezonu / Pub Date Season: Nisan / April

Bu Makaleye Atıf İçin / To Cite This Article: Gül, M. F. (2021). Osmanlı Devleti'nde Kapitülasyonların Kaldırılması Sonrasında Halkın Tepkilerine Dâir Bazı

Tespitler. USBAD Uluslararası Sosyal Bilimler Akademi Dergisi 3(5), 732-754.

Intihal: Bu makale intihal.net yazılımınca taranmıştır. İntihal tespit edilmemiştir. Plagiarism: This article has been scanned by intihal.net. No plagiarism detected.

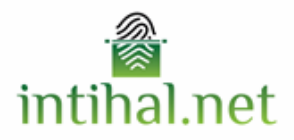

İletişim: Web: https://dergipark.org.tr/tr/pub/usbad mail: usbaddergi@gmail.com 
Öz: Dünya tarihinde birçok devletin kapitülasyonlarla tanışıklığı vardır. Kapitülasyonların oldukça uzun süre ve zararını daha belirgin yaşayan devlet Osmanlı Devleti'dir denilebilir. Osmanlı Devleti'nin zararı sadece ekonomik değildir. Osmanlı Devleti'nin bağımsız yapısının da etkilendiği dönemin yöneticileri tarafından fark edilmiştir. Devletin ve milletin zararına olan bu uygulamaların varlığı ve bu durumdan kurtulabilmek için uzun süreçte farklı çareler düşünüldüğü belgelere yansımıştır. Osmanlı Devleti yöneticileri 18. yüzyıldan itibaren özellikle Tanzimat dönemi sonrasında kapitülasyonlardan kurtulabilmenin çarelerini aramıştır. Osmanlı Devleti'nin her girişimi sonrasında mağduriyeti daha da artmıştır. II. Meşrutiyet sonrasında iktidara gelen İttihat ve Terakki Hükûmeti de kapitülasyonlardan kurtulmanın fırsatını kollamıştır. Birinci Dünya Savaşı'nın sebep olduğu gerginlik ve Avrupalı Devletlerin karşı karşıya gelmesini de fırsat bilen Osmanlı Devleti tek taraflı olarak kapitülasyonları kaldırdığını duyurmuştur. Bu karara Avrupalı devletlerin tamamına yakını itiraz etse de Osmanlı halkını çok mutlu etmiştir. Başkent İstanbul başta olmak üzere ülkenin önemli bir kısmında özellikle de Anadolu'da kapitülasyonların kaldırılması büyük sevinçlerle karşılanmış, gösteriler düzenlenmiştir. Kapitülasyonların kaldırımasının milli bayramlar gibi kutlanması bile gündeme gelmiştir. Gerçi daha ilk yıldönümünde bile kapitülasyonların kaldııımasını neredeyse hatırlayan olmamışır ama 1914 yılında kapitülasyonların tek taraflı da olsa kaldırılması yıllardır acısını en derinden hissedenlerin gururunu okşamıştır.

Anahtar Kelimeler: Kapitülasyon, Avrupalı Devletler, Osmanlı Devleti, İstanbul, Anadolu Şehirleri

Abstract: Many states in the history of the world are familiar with capitulations. It can be said that the state that experienced the capitulations for quite a long time and the damage more obvious is the Ottoman State. The damage to the Ottoman Empire is not only economic. It was noticed by the rulers of the period that the independent structure of the Ottoman State was also influenced. The existence of these practices to the detriment of the state and the nation, and different remedies were considered in the long process to get out of this situation, were reflected in the documents. Ottoman rulers 18 th from the century on, but especially after the Tanzimat period, he sought remedies to get rid of capitulations. After each attempt of the Ottoman Empire, its victimization increased even more. II. The Government of Union and progress, which came to power after legitimacy, also sought the opportunity to get rid of capitulations. The Ottoman State, which also had the opportunity to confront the tensions caused by the first World War and the European states, unilaterally announced that it had abolished the capitulations. Although almost all European states objected to this decision, it made the Ottoman people very happy. In a significant part of the country, especially in the capital Istanbul, the abolition of capitulations was met with great joy and demonstrations were organized. The abolition of capitulations has even been celebrated as national holidays. Although no one almost remembers the 
abolition of the capitulations even on the first anniversary, but the unilateral abolition of the capitulations in 1914 has flattered those who have felt the pain most deeply for many years.

Keywords: Capitulation, European States, Ottoman State, Istanbul, Anotlian Cities

\section{GİRİ̧̧}

Latince bir kelime olan kapitülasyonun "sözleşme yapma" anlamındaki "capitulare" kelimesinden geldiği tahmin edildiği (Pamir, 2002: 80) gibi kral ve kilise emirnamelerinin bir bölümü anlamındaki Latince "capitulum"dan türemiş İtalyanca "capitplazione" kelimesine dayandığını (Elmacı, 2001: 1) yazanlar da vardır. Bazıları da "bir kumandanın müdafa ettiği mevkiyi ve emri altındaki askeri düşmana bırakacak olunca teslim şartlarını havi olarak tanzim edilen senede Fransızcada kapitülasyon" dendiğini iddia etmektedir (A. Reşid, 1923: 3).

Kapitülasyonlar sadece Türk tarihiyle ilgili bir kavram değildir. Bir ada ülkesi olan Japonya bile zamanında kapitülasyonla mücadele etmek zorunda kalmıştır (Cudi, 1915: 181). Kavram olarak kapitülasyon "Avrupalı devletlerin kendi ülkeleri dışında sürekli ya da geçici olarak bulunan yurttaşlarının, ülkesinde bulundukları devletin yetkilerine değil de kendi devletlerinin yetkilerine tabi olmak biçiminde elde ettikleri ayrıcalıklarla, ticaret ve gümrük konularında elde ettikleri kolaylıklar ve ayrıcalıklar düzeni" şeklinde değerlendirilmektedir (Pamir, 2002: 80).

"İmtiyazlar, genellikle ilgili ülkede serbest ticaret ayrıcalığı yanında ulaşım, haberleşme ve finans sektörlerinin, yer altı ve yer üstü doğal kaynakların işletme tekellerini ele geçiren, bütün bu yatırımlara tehdit oluşturan iç ve dış düşmanlara karşı istikrarı sağlamak için hükümetlere siyasî baskı yapan Avrupa devletlerinin yavaş fakat istikrarlı sömürgeleştirme politikalarını yansıtır" (Kallek, 2000: 245).

Yabancıların Osmanlı topraklarında kurumlar açmaları ve bu yolla mülkiyet edinmelerini sağlayan en önemli gelişme ise kapitülasyonlardır. Her ne kadar kapitülasyonlarda yabancıların mülk edinmeleri düzenlenmemişse de kapitülasyon hakkı elde etmiş olan devletler bu ayrıcalıklarından faydalanarak sağlık, eğitim, iletişim, malî ve adlî alanlarda birtakım kurumlar kurarak kendilerine mülkiyet alanı meydana getirmişlerdir (Karabulut, 2018: 452).

Osmanlı Devleti, kapitülasyonlar yerine 19. Yüzyılın ikinci yarısından önce ahidnâme haricinde "imtiyaz", imtiyâzât", "imtiyâzât-ı ecnebiyye", 
"uhûd-i kadîme" veya "uhûd-i atîka" tabirlerini/ifadelerini tercih etmiştir. Kapitülasyon terimi Osmanlı Devleti'nde XIX. yüzyılın ikinci yarısından itibaren kullanılmaya başlamıştır (Külünk, 2006: 4).

Osmanlı Devleti'nin ilk kapitülasyonu hangi tarihte hangi devlete verildiği tartışma konusudur. Daha 14. Yüzyılın ikinci yarısının hemen başında Cenevizlilere bazı imtiyazlar verildiği ya da Kanuni döneminde başladığı görüşleri vardır. Daha çok kabul gören görüş 1536'da Sultan Süleyman döneminde başlayan süreçle alakalı olarak 1569 verilen imtiyazların ilk gerçek kapitülasyon olduğudur (İnalcık, 2000: 248).

İnalcık'ın da belirttiği gibi esasında sadece Avrupalı devletlerin faydasına gibi görülen imtiyazlardan Osmanlı Devleti de istifade etmek istemiştir:

"İmtiyaz olarak bağışlanan ahidnâmelerden zımnen karşılıklı menfaatler beklenir, bunlar karşılıklı olarak gerçekleşmezse padişah daha önce mevcut olan dostluk ve samimiyetin bozulup ihlâl edildiğini belirterek ahidnâmeyi ilga edebilirdi" (2000: 246).

Fakat Osmanlı Devleti uzun bir süreçte kapitülasyonlardan çok zarar görmüştür. Rahatsız olduğu bu ayrıcalıkları kaldırması kolay olmamıştır. Birazdan değinileceği gibi 1914'te, Birinci Dünya Savaşı'nın arifesinde Avrupalı devletlerin karşı karşıya gelmesini de fırsat bilerek Osmanlı Devleti tek taraflı da olsa kapitülasyonları kaldırmıştır. Ayrıca Düyun-ı Umumiye'nin de faaliyetleri askıya alınmıştır (Semiz-Kodaz, 2019: 3805). Birinci Dünya Savaşı'ndan yenik ayrılan Osmanlı Devleti 1918 sonrasından Lozan'a kadar evvelinde uygulanan kapitülasyonların daha fazlasını yaşamak zorunda kalmıştır.

Birinci Dünya Savaşı'ndan yenik çıkan ordudan geriye kalanlar ne kadar az olsa da Türk milleti özgürlüğün tadını biliyordu ve esaretten Gazi Mustafa Kemal Paşa liderliğinde kurtulacağına inanmıştı. Kazanılan İstiklal Harbi'nden sonra Türk milleti aynı zamanda özgürlüğünü de kazanmıştı. Cumhuriyet'in ilanı sıradan bir hadise değildi. Yeni bir devlet kurulurken ayağındaki prangalardan kurtulmak demekti. En önemli meselelerden birisi de kapitülasyonların tamamen kaldırılmasıydı. Atatürk'ün ifadesiyle "Lozan'da: Kapitülasyonların her nev'i tamamıla ve ebediyen lağvolunmuştur" (Atatürk, 1927: 545). Zira Lozan Barış Antlaşması ile elde edilen başarıların en önemlilerinden biriydi (Cevizliler, 2019: 188). 


\section{KAPİTÜLASYONLARIN KALDIRILMASI SÜRECI்}

Osmanlı Devleti, kapitülasyonları ilk verdiği zaman (16. yüzyılda) gücünün zirvesindeydi denilebilir. Ahidname adı altında verilen ve ilk kapitülasyonlar olarak kabul edilen bu imtiyazlara o dönemde bir ihsan yani bağış olarak bakılıyordu. Fakat zamanla bu bağış bir külfete dönüştü. Osmanlı Devleti'nin zamanında verdiği imtiyazatın zararını net olarak gördüğü tarihten itibaren bundan kurtulmak istediği rahatlıkla söylenebilir. Günümüzdeki ifadeyle taviz tavizi doğurduğundan devletin iktisadî ve adlî sisteminde çok ciddi zarara sebep olan kapitülasyonların kaldırılması umulduğu gibi olmamıştır. 16. yüzyılın ilk yarısında kolaylıkla verilen kapitülasyonlar üç asır sonra devletin başına bela olmuştur.

Kapitülasyonlardan kurtulmanın gerekliliğini ilk fark eden ya da ilk defa dillendiren kişinin Sadrazam Damat (Şehit) Ali Paşa olduğu düşünülmektedir. 1713'te sadrazam olan Ali Paşa kapitülasyonların ve Katolik misyonerlerin faaliyetlerinin tamamen bertaraf edilebilmesi gayretinin temelinde kapitülasyonların hukuksal temelinin zayıf olduğunu fark etmesi vardır (Elmacı, 2001: 20). 5 Ağustos 1716'da Avusturya Ordusu'na karşı yapılan Petrovaradin Muharebesi'nde şehit düşmesinden dolayı kapitülasyonları sömürme aracı gibi görenlerle mücadelesi yarım kalmıştır.

Tanzimat döneminde Osmanlı Devleti sanayileşme hususunda da bazı düzenlemeler yapmaya çalışmıştır. Olumsuz etkileri bilinen kapitülasyonlardan kurtulmak isteyen Osmanlı Devleti sanayi üzerindeki etkisinin daha fazla olduğunu anlamıştır. 19. yüzyıl ticaret antlaşmalarıyla küresel ekonomik sisteme dahil olan devletin ekonomisinin yanı sıra Avrupa devletlerine verilen ayrıcalıklar yüzünden yerli sanayi sağlam temeller üzerinde değildir (Aker, 1999: 98). Osmanlı Devleti bu sebepler başta olmak üzere diğer unsurlarında etkisi sebebiyle Avrupalı devletlerin sanayi seviyesinin altında kalmaya mahkûm olmuştur denilebilir. İnalcık'ın ifadelerine göre,

"Tanzimat dönemi devlet adamları artık kuvvetle inanıyorlardı ki Osmanlı Devleti'nin toparlanması ve bağımsızlığı konusundaki ilk ve temel adım kapitülasyonlardan kurtulmakla atılacaktı" (İnalcık, 2000: 250).

Bu maksatla Batılılaşma ve idare ile yargı sisteminin laikleşmesinde esaslı tedbirler alırken bir taraftan da kapitülasyonların kötüye kullanılmasını önleyecek tedbirlerin yollarını araştırdılar. Örneğin, Tanzimat dönemi aydınlarından Ziya Paşa Osmanlı Devleti'nin başına bela olan 
kapitülasyonlarla alakalı olarak ülkedeki yabancıların taşradaki müdahalelerine dikkat çektiği gibi İstanbul'daki elçilik görevlilerinin haddini epeyce aşmasından haklı olarak çok rahatsızdır. Sıradan bir insana bile söylendiğinde utandıran sözleri elçilik görevlilerinin sadrazamlara söyleyebildiğini ifade etmektedir (Elmacı, 2001: 16). Aynı pervasız ve cüretkâr kişilerin Osmanlı Devleti'nde olağanüstü zenginliği de ayrı ve can sıkıcı bir meseledir.

Kapitülasyon imtiyazları görüldüğü üzere ilk verildiği 16. yüzyıldan sonra çok farklı bir duruma gelmiştir. Kapitülasyonlardan faydalanan Avrupalı devletler, Osmanlı Devleti'ni gizliden ve derinden sömürmüştür. Osmanlı Devleti'nin bir yerde sömürge ülkesi gibi görülmesine neden olan bu istismar için İnalcık şöyle yazar:

"İstismarın ve misyoner faaliyetlerin arkasında emperyalist devletlerin siyasî ve askerî baskısı vardı. Tehlikenin farkında olan Türkiye'deki kamuoyu kapitülasyonlara şiddetle karşı çıkmaya başladı. 1908'den itibaren her hükümet kapitülasyonların kaldırılmasını programının başına aldı" (2000: 251).

Osmanlı Devleti'nin 1838 'de İngiltere ile imzaladığı ticarî antlaşmanın şartlarına bakıldığında İngilizlerin evvelki imtiyazlardan vazgeçmediği görülür. Bu ticarî antlaşmanın Osmanlı Devleti'nin mi yoksa İngiliz Hükûmetinin mi faydasına olduğu kısa süre sonra fark edilmiştir. 16 Ağustos 1838 tarihli Balta Limanı Antlaşması Osmanlı Devleti'nin zaten iyi olmayan sanayisini perişan etmiştir denilebilir. Bu antlaşma bilindiği gibi İngiltere ile yapıldı ama sonraki yıllar pek çok devlet (Fransa, İsveç, Norveç, İspanya, Hollanda, Belçika, Danimarka ve Portekiz) benzer imtiyazlara sahip olmuştur. Bu imtiyazlar kapitülasyonların daha pekişmesini sağlamış ve haliyle de ekonomik sistemi felce uğratmıştır. Kaçınılmaz olarak borç alan Osmanlı Devleti'nin mali çöküntüsü hızlanmıştır (Yerlikaya, 2011: 60). 1861-1862'de Avrupalı ülkeler ile Osmanlı Devleti'nin yaptığı yeni antlaşmalarda yalnızca gümrük oranlarında bazı değiş̧iklikler olmuştur (Külünk, 2006: 10).

Farklı yıllarda bazı girişimler olsa da bunların kapitülasyonları kaldırmak için yeterli olmadığı hatta hiç işe yaramamıştır. Osmanlı Devlet adamlarının yabancıların posta idarelerini kapatması için yaptıkları çağrılara cevap dahi verilmediği, Osmanlı'yı ciddiye bile almadıkları fark edilince başka bir şekilde müdahale edilmesi anlaşılmıştır. Bunun için en iyi stratejinin kapitülasyonları tümden kaldırmaya çalışmak yerine sorunlara ayrı ayrı yaklaşmak olduğuna karar verilmiştir. 
1856 tarihli Paris Kongresi'nde Âlî Pasa "hem bize reform yapmamız için baskı yapıyorsunuz hem de kapitülasyonlarla önümüzü kesiyorsunuz" serzenişiyle başlayan konuşmasında kapitülasyonların Osmanlı Devleti'ne çok ciddi zarar verdiğini, uygulamaların aslında devlet içinde devlet olduğunu yüksek perdeden ifade etmişse de netice alamamıştır. "Kapitülasyonların kaldırıması için 1862, 1867, 1869 ve 1871 tarihlerinde yapılan girişimler de başarılı olamamıştır" (Külünk, 2006: 13, 14). Zira güçlü olan haklı olduğu için gerçekte haklı olan Osmanlı Devleti alenî bir paralel devleti yok edememiştir.

Birinci Dünya Savaşı'nın sebep olduğu ortamda İttihat ve Terakki de devletler arasındaki bloklaşmayı, gerginliği lehine çevirmenin ilk adımlarından birisinin asırlardır Osmanlı Devleti'nin kamburu olan imtiyazları kaldırmak olduğunun farkındaydı.

Rusya bilindiği gibi Osmanlı Devleti'ni oldukça uzun süreli planlarının önündeki engel olarak görmüştür. Rus devlet adamları, Birinci Dünya Savaşı'yla planlarının önemli bir kısmını hayata geçirmesine fırsat verebileceğini hesap ettiği gibi Osmanlı Devleti'nin Almanya ile birlikte hareket etmesini de engellemeye çalışmıştır. Zira Ruslar Almanları en önemli rakipleri hatta düşmanı olarak görmüştür. Avrupa'da savaşın başlaması ve dalganın gittikçe genişlemesiyle devletler bloklarını sağlamlaştırmak ve genişletmeyi de ihmal etmemiştir. Kararsız devletlerin bazılarını yanlarına çekebilmek için politikalar takip etmişlerdir. Osmanlı Devleti de kararsız devletlerden birisi olduğundan özellikle Almanların hedefindeydi. Türkler de yalnız kalmamak için sağlam bir ittifakın içinde yer almak istemiş ve birçok görüşme yapmıştır.

2 Ağustos 1914'te Türk-Alman gizli antlaşmasından sonra Alman gemilerinin (Goeben ve Breslau) Osmanlı Devleti tarafından satın alındığının ilanı İtilaf Devletleri'nce şaşırtıcı olmuştur. Bu gelişme üzerine başta Ruslar olmak üzere İngiltere ve Fransa, Osmanlı Devleti'nin alacağı pozisyonu bekleyip görmek yerine gelişmeleri etkileyen taraf olmak istemiştir. Yakın bir tarihte Rus dışişleri arşivi gizli belgelerinin bir kısmı araştırmacılara açılmıştır. Bu gizli belgelerden önemli bir kısmı da telgraflardır. Rus dışişleri arşivindeki gizli telgraflardan Osmanlı Devleti'ni doğrudan ilgilendirenler 2018'de yayımlanmıştır (Ağaoğlu, 2018). Bu telgraflar birçok olayın bilindiği gibi olmadığını ortaya çıkarmıştır. Yine bu gizli telgraflardan birçok olayın bilinmeyen ayrıntıları öğrenilmiştir. Britanya İmparatorluğu, Fransa ve Rusya, Osmanlı Devleti'nin kendi yanlarında olmasını, hiç olmazsa tarafsız kalmasını istediğinden farklı tekliflerde bulunmuştur. Bu tekliflerden birisi de kapitülasyonların kaldırılmasına razı olacaklarıyla alakalıdır. Rusya 
Dışişleri Bakanı Sazonov'dan Rusya'nın İstanbul elçisi Giers'e 23 Ağustos 1914 tarihinde çekilen gizli telgrafta "İngiltere, kapitülasyonlar sayesinde gerçekleşen bölgesel yargı yetkisinden vazgeçmeyi kabul edecektir" diye yazmaktadır (Ağaoğlu, 2018: 81). İlerleyen süreç bu devletlerin takiye yaptığını göstermiştir.

Kapitülasyonların kaldırılması kararını elbette Osmanlı Devleti (İttihat ve Terakki Hükümeti) vermiştir ama hukukî dayanağı ve resmî gerekçesi için bir komisyon görev yapmıştır. Adliye Nazırı Pirîzade İbrahim Bey bu komisyonun başkanıydı. 8 Eylül 1914'te toplanan İttihat ve Terakki Hükümeti kapitülasyonların kaldırılması gerekçelerini uygun görerek aynen kabul etmiştir (Külünk, 2006: 304).

8 Eylül 1914 tarihli ve Padişah V. Mehmed Reşad'ın iradesi "kapitülasyon" adı altında yabancı ülke vatandaşlarına verilmiş olan bütün mali, iktisadi, adli ve idari imtiyazların ve bunlarla ilgili tüm müsaade ve hukukun ilga edildiği ve 1 Ekim 1914 tarihinden itibaren bunların geçerli olmayacağını ifade ediyordu (BOA, İ.MMS, 188/22-5; Takvim-i Vekayi, 17 Eylül 1914; Düstur, Tertib-i sâni: 1273). Gazetelerde ve dergilerde kapitülasyonların ilgasıyla alakalı olarak pek çok yazı mevcuttur. Gazete ve dergilerde kapitülasyonların ilgasıyla alakalı olarak hükümet-i ecnebiyeye çekilen nutkun suretleri neşredilmiştir (bkz. Sebilürreşad, 4 Eylül 1330, 417). Avrupalı devletlere verilen nota dahil olmak üzere kapitülasyonların kaldırılması basında epeyce yankı bulmuştur (bkz. Sebilürreşad, Nr.310).

Kapitülasyonların kaldırıldığını bildiren padişah iradesinin konsoloslara ayrıca bildirilmesinin gerekip gerekmediği konusunda bazı valiler Dahiliye Nezareti ile yazışma yapmıştır. Erzurum Vali Vekili Defterdar Cemal Bey'den Dahiliye Nezareti'ne gönderilen 12 Eylül 1914 tarihli şifreli telgrafta kapitülasyonların ilga edildiğine dair, Erzurum'daki konsolosluklara da tebligat yapılmasının uygun olacağı kayıtlıyken (BOA, DH.ŞFR, 440/67) bir gün sonraki tarihli (13 Eylül 1914) yine şifreli ve Dahiliye Nezareti'nden Erzurum Vilayetine çekilen telgrafta kapitülasyonların ilga edildiğinin nezaret tarafından konsolosluklara tebliğ edilmesine gerek olmadığı bildirilmiştir (BOA, DH.ŞFR, 44/239). Osmanlı Devleti'ndeki memurlar için ayrıca bir talimatname yayımlanmıştır (BOA, BEO, 4309/323145-60-1-9).

Ayrıcalıklara alışan ve bunun devam etmesini çok isteyen Avrupalı devletler kapitülasyonların devam etmesi için çok uğraşmış, bunun gerçekleşmemesi durumunda ise Osmanlı Devleti'nin savaşa girmemesine karşılık bir pazarlık aracı olarak kullanmışlardır (Arslan, 2008: 274). Kapitülasyonların ilga kararı sonrasında bazı devletler Osmanlı Devleti'nde 
yaşayan ırkdaşları için endişelenmiştir. Tarafsız devletlerden olan Amerika Birleşik Devletleri, kapitülasyonların kaldırılması sonrasında herhangi bir olayın hatta Osmanlı Devleti'ndeki yabancılara karşı saldırıların olabileceği kaygısını taşımıştır. Makalenin ikinci bölümünde birazdan izah edilmeye çalışılacağı gibi kapitülasyonların kaldırılmasının sevinciyle Sivas'ta bir esnafın Amerika bayrağını indirmesi olayının o gün ya da birkaç gün içinde Amerika'da duyulması söz konusu mu tespit edilememiştir. Amerika Birleşik Devletleri'nin Osmanlı Devleti'nin kapitülasyonları kaldırmasına dair merakı ya da tedirginliğiyle alakalı olarak Osmanlı Devleti ve Kapitülasyonlar başlıklı bir çalışmada bazı bilgiler mevcuttur.

"Amerika'da kapitülasyonların kaldırıldığı haberini 11 Eylül'de Washington Post ve 12 Eylül'de Evening Star gazeteleri Amerikan halkına duyurmuştu. İlga kararının kaygıyla karşılanması üzerine New York'taki Osmanlı konsolosu Celal Münif Bey, Amerika kamuoyuna Osmanlı topraklarındaki Amerikalıların hayatlarının ilgadan önceki döneme kıyasla daha fazla güvende olduğunu ve endişelerinin yersiz olduğunu ifade etti. Ancak Amerika efkâr-ı umumiyetinde kapitülasyonların kaldırılmasının Türklerin katliam yapmasına sebep olacağına ilişkin kaygılar sürekli olarak gündemdeydi. Bunun üzerine Osmanlı Devleti'nin Amerika'daki büyükelçisi Alfred Rüstem Bey, Amerika kamuoyuna açıklamalarda bulunmuş; ayrıca Amerika gazetelerine gönderdiği yazılarla da kapitülasyonların zararlarına ve kaldırılmasının haklılığını vurgulamıştı" (Yerlikaya, 2011: 98).

Asırlardır Osmanlı Devleti'ni müstemleke gibi gören devletler tahmin edileceği gibi kapitülasyonların kaldırılmasını kabul etmek istemediler. Dönemin idarecileri yani İttihat ve Terakki liderleri başta olmak üzere Osmanlı Devlet adamları kapitülasyonların kaldırılmasına Avrupalı devletlerin itiraz edeceğini biliyorlardı fakat 2 Ağustos 1914'te yani yaklaşık bir ay önce gizli ittifak kurdukları Almanların diğer devletlerden de önce Osmanlı Devleti'nin bu kararını reddedeceğini düşünmemişlerdi. Almanların bu yüksek perdeden itirazı hiç hesapta yoktu denilebilir (Arslan, 2008: 266). Ama iş menfaate gelince ittifak ya da itilaf bloğu fark etmeden Osmanlı Devleti'ni sömürmekten vazgeçmeye yanaşmadılar. İngiltere ve Fransa bu kararın iptal edilmesi için çok uğraşsalar da Türklerin ilerleyen günlerdeki ciddiyetinin farklı cephelerini de görünce yeni planlar yapmışlardır (Komisyon, 2013: 59).

Kapitülasyonların tam olarak kaldırılığı tarih 8 Eylül 1914 tarihli padişah iradesi değildir. Gazi Mustafa Kemal Paşa'nın Nutuk'ta da belirttiği gibi Lozan'daki maddelerde yer almaktadır. Cumhuriyetin ilk yıllarında 
kapitülasyonların tam olarak kaldırılığı tarihle alakalı yazılara da rastlanılmaktadır (Salem, 1926: 81).

\section{KAPİTÜLASYONLARIN KALDIRILMASI SONRASI HALKIN DUYGULARI}

Kapitülasyonların kaldırılması kararının alınması, Osmanlı basını ve halkı tarafından sevinçle karşılanmıştır. Osmanlı bürokratlarından ve halkın çeşitli kesimlerinden merkeze gönderilen telgraflarda kapitülasyonların kaldırılması, Osmanlı Devleti'nin yenileşmesine, gelişmesine, ilerlemesine, istiklal ve hâkimiyetine engel olan bağlardan kurtuluş olarak görülmüştü. Kapitülasyonların kaldırılmasıyla Osmanlı tebaasının iktisadî alanda eşit şartlarda rekabet etme olanağına kavuşması Osmanlı tebaasının sevincini artırmıştı. İlga kararıyla yeni bir döneme geçildiği düşüncesi ağırlık kazanmış; karar, bir milat olarak görülmüştü (Külünk, 2006: 304). Türkiye'deki Alman misyonunun ünlü kumandanlarından Liman von Sanders, hatıralarında halkın duygularına dair "kapitülasyonların kaldırılmasından sonra "Türkiye Türklerindir" sözü her tarafta söylenmekteydi" yazmıştır (1999: 57).

Osmanlı Devleti ahalisi kapitülasyonların kaldırılması haberine çok sevinmiş, İstanbul başta olmak üzere başka şehirlerinde de görkemli etkinlikler düzenlemiştir (Yerlikaya, 2001: 116). İstanbul'da yapılan gösterilerin coşkusuyla bu özel ve anlamlı günün millî bayram olarak ilan edilmesi talep edilmiştir. Kapitülasyonların kaldırılmasına dair padişah iradesi miladî takvimle 8 Eylül 1914; rumî takvime göre ise 27 Ağustos 1914 olduğundan gazetedeki haber başlığı da "27 Ağustos İd-i Millîsi" olarak verilmiştir. Bugünün (27 Ağustos) her sene bayram olarak kutlanmasının hükümet tarafından kanunlaştırılacağının haber alındığı yazılıdır (İkdam, 12 Eylül 1914).

Devletin ve milletin başına bela olan kapitülasyonların artık tarih olduğunu duyan halkın sevinci tahmin edilir ki büyük bir coşku içinde olmuştur. Bu tahminin doğru olduğu o günleri yaşayan ve yazan bazı devlet adamlarının hatıralarında yer aldığı gibi dönemin gazetelerine de yansımışır. Halkın bu sevincinin mimarı olarak padişah değil dönemin iktidar partisi İttihat ve Terakki Hükümeti görülmüştür. Bu elbette haklı bir değerlendirmedir. Kapitülasyonların kaldırılması hem siyaset hem de cesaret işi olarak görüldüğünden İttihat ve Terakki'nin karizması pekişmiştir denilebilir. Hükümet ve halk bu mutlulukla başkent İstanbul'un her tarafını süslemiştir. 
"Caddeler on binlerce kişiden oluşan göstericilerin yürüyüşlerine ve tezahüratlarına sahne olmuştu. Gösterici kafilelerinin çoğunun önünde yer alan mızıka takımlarının veyahut davulların, zurnaların çaldığı millî havalar ile İstanbul adeta bir karnaval havasına bürünmüştü: Beyoğlu, Üsküdar, Kadıköy, Sisli, Bakırköy, Beşiktaş, Kasımpaşa, Eyüp, Boğaziçi ve daha birçok yere göstericilerin kutlamaları aksetmişti. Göstericiler kalabalık kafileler halinde İstanbul'un değişik semtlerini dolaşarak belediye dairelerinin, vükela konaklarının önünde ve bazı meydanlarda toplanarak kapitülasyonların kaldırılmasından duydukları şükranı ifade eden nutuklar söylemiş, alkışlarla tezahüratlarda bulunmuşlardı. İstanbul'da, haberin yayıldığı çeşitli yerlerde dükkânlar, kahvehaneler ve evler bayraklarla donatılmıştı" (Külünk, 2006: 54).

Günümüzde de olduğu gibi 1914 yılında kapitülasyonların sevincinin yaşandığı adresler öncelikle ve özellikle meydanlar olmuştur. Bu husus Anadolu'nun geneli için böyledir diye düşünülebilir ama İstanbul ile bilgi gazetelere yansımıştır.

Başkent İstanbul ile alakalı kıyaslandığında taşradaki insanların duyguları hakkındaki bilgi azdır ama yine de belgelere ve gazetelere yansıyan haberler vardır. Kapitülasyonların kaldırıldığını haber veren Padişah iradesinin hemen ardından halk da bu önemli gelişmeyi öğrenmiştir. Kapitülasyonların kaldırıldığını 10 Eylül 1914 tarihi itibariyle öğrenen halkın tamamının sevindiği düşünülmektedir. Fakat arşivdeki belgelerden ve gazetelerden bazı vilayetlerden gelen telgraflar tespit edilebilmiştir.

12 Eylül 1914 tarihli İkdam Gazetesi'nde "Taşrada Tezahürat" başlığı altında Cisr-i Şuğur'dan, Teke'den, Kütahya'dan, Balıkesir'den, Musul'dan, Kütahya'dan (birkaç esnaftan ayrıca), Dimetoka'dan, Gelibolu'dan, Sivas'tan, Pangaltı'dan, Humus'tan, Edirne'den ve İstanbul Belediyesi'nden gelen telgraflar kayıtlıdır (İkdam, 12 Eylül 1914).

Osmanlı Arşivi'ndeki belgelerden birkaç vilayetten gelen telgraf tespit edilebilmiştir. 12 - 14 Eylül 1914 tarihleri arasında Adana, Süleymaniye, Van ve Erzurum'dan çekilen telgrafların içeriği genel olarak aynıdır. Adana Valisi İsmail Hakkı Bey'den Dahiliye Nezareti'ne çekilen telgrafta kapitülasyonların kaldırılığı haberinin verildiği 10 Eylül gününden beri vilayet merkezi ile bağlı yerlerde geceli gündüzlü kutlamalar yapıldığı (BOA, BEO, 4309/323145-40); 13 Eylül 1914 tarihli ve Süleymaniye Mutasarrıflığından Musul Vilayetine gönderilen yazıdan kapitülasyonların kaldırılması üzerine Süleymaniye şehrinde dört-beş bin kişilik bir kalabalığın 
hükümet binası önünde toplanarak gösteri yaptığı, yapılan konuşmalarda kapitülasyonların kaldırılmasından duyulan memnuniyetin dile getirildiği ve Padişah ve hükümete teşekkür edildiği*; bir gün sonraki tarihli (14 Eylül 1914) ve Musul Valisi Süleyman Nazif Bey'den Dahiliye Nezareti'ne gönderilen yazıdan da Süleymaniye halkının kapitülasyonların kaldırılmasına çok sevindiği, gösteri yaptıkları ve bu başarıdan dolayı hükümeti tebrik ettikleri kayıtlıdır ${ }^{\dagger}$. 14 Eylül 1914 tarihli ve Van Valisi Hasan Tahsin Bey'den Dahiliye Nezareti'ne çekilen telgrafta ${ }^{\ddagger}$ sevinç haricinde bir de halkın devletine yapacağı maddi yardımdan bahis vardır. Telgrafta kapitülasyonların kaldırılmasından dolayı Çölemerik halkının büyük bir sevinç içinde olduğu ve belediye başkanı, Nasturi reisi ve idare meclisi üyelerinin telgrafla bildirdiklerine göre on gün içinde 50 bin kuruşluk yardım toplayacakları bildirilmiştir (BOA, BEO, 4309/323145-23).

Aynı gün tarihli (14 Eylül 1914) başka bir telgraf ise Erzurum Vali Vekili Defterdar Cemal Bey'den Dahiliye Nezareti'ne çekilmiştir. Kapitülasyonların kaldırımasından dolayı bütün vilayette olduğu gibi

\footnotetext{
* Süleymaniye Mutasarrıflığı'nın 31 Ağustos sene [1]330 [13 Eylül 1914] tarihli telgrafnamesi suretidir, [Süleymaniye Mutasarrıflı̆ıı'ndan Musul Vilayeti'ne],

Uhud-ı atika ilgasına müteşekkiren bugün saat dokuz buçukda daire-i hükümet pişgahına dört beş bin kişi toplandı, izdiham o derecede idi ki civarda bulunan mebani sütuhu bile büyük kesafetle lebaleb dolmuş idi, esnaf dükkanları kapadıkları gibi herkes işini gücünü terk etmiş ve bi'l-umum tekaya dervişanı da izkar ve tehlil ile isbatI vücud etmiş idi, burada bu misillü bir ictima ilk defa olarak vaki olmuş iken halkın gösterdiği intizam ve dağıldıkdan [sonra] ittihaz eyledikleri tavr-ı sükun muhakkak gayr-i mesbuk bir derecede[dir], hatibler tarafından evvela uhud-ı atikanın derece-i mazarratı ve sonra da bunun lağvından iktitaf olunacak fevaid ve bundan böyle de millete terettüb eden vezaif [Türkçe] ve Kürdce izah olunarak azim ibtihac ve teşekküratla ictimaa hatime verilmiş ve hilafet-penah efendimiz [ile] kabinenin tevali-i muvaffakiyetine kalbi dualar eda ve teşekkürlerinin iblağı acizlerinden rica olunmuş olmağla maa'l-iftihar arz-ı keyfiyet olunur.

Fi 31 Ağustos sene [1]330 [12 Eylül 1914], BOA, BEO, 4309/323145-54.
}

${ }^{+}$BOA, BEO, 4309/323145-55.

[Musul Vilayeti'nden],

Dahiliye Nezaret-i Celilesi'ne,

Devletlü efendim hazretleri,

Uhud-ı atikanın ilgasından dolayı fevkalade mütehassis olan Süleymaniye ahalisinin bi'l-ictima hükümetin bu babdaki muvaffakiyetini tebcil ile arz-ı şükran etdiklerine dair Süleymaniye Mutasarrıflığı'ndan alınan telgrafnamenin bir sureti leffen takdim kılındı, ol babda emr ü ferman hazret-i men lehü'l-emrindir.

Fi 24 Şevval sene [1]332 ve fi 1 Eylül sene [1]330 [14 Eylül 1914]

[imza] Musul Valisi Süleyman Nazif

${ }^{\ddagger}$ [Van Vilayeti'nden],

Mahreci : Van

Dahiliye Nezaret-i Celilesi'ne,

Kapitülasyonların lağvı Çölemerik ahalisince de fevkalade bais-i ibtihac ve meserret olduğu ve on güne kadar yeniden elli bin kuruş iane taahhüd edildiği mahalli belediye reisi ve Nasturi reisi Mer [Benyamin] Şimun Efendi ile meclis-i idare azası tarafından telgrafla işar kılınmış ve vilayetce de kendilerine beyan-ı teşekkürat edilmişdir. Fi 1 Eylül sene [1]330 [14 Eylül 1914]

[imza] [Van] Vali[si] [Hasan] Tahsin 
Bayburd, Hınıs ve Namervan kasabalarında da sevinç gösterileri yapıldığı bildirilmiştir (BOA, BEO, 4309/323145-44).

Avrupalı devletlerin asırlarca Osmanlı Devleti'ni imtiyazlar sebebiyle sömürmesi sadece yöneticileri değil aynı zamanda halkı da ilgilendiriyordu. Mütegallibe gibi davranan bazı Avrupalıların bu davranışlarının etkisi Türkleri canından bezdirmişti. Adeta bu kapitülasyonların kaldırılmasının mümkün olmadığı, olamayacağı gibi bir karamsarlık sonrasında artık imtiyazların son bulduğunun ilanı Anadolu insanını çok mutlu etmişti. Kapitülasyonların sadece ekonomik yönü yoktu aynı zamanda devletin egemenliğiyle de alakalı sorunların başlıca kaynağı olarak değerlendiriliyordu. İşte bu yüzden kapitülasyonların kaldırılması haberine sevinenlerden bazıları Osmanlı'da ticaret yapan yabancılara tepkilerini farklı göstermiştir.

Yılların kızgınlığının da getirdiği duygularla Sivas'ta müstakil bir olay yaşanmıştır. Sivas'taki Singer mağazasındaki Amerika bayrağı indirilmiştir. Bu hadise hemen değil de aylar sonra Osmanlı Hükümeti'ne duyurulmuştur. Olaydan yaklaşık 4 ay sonra 1915 yılının ilk günlerinde olayın doğru olup olmadığı araştırılmıştır. 2 Ocak 1915 tarihli ve Dahiliye Nazırı namına Emniyet-i Umumiye Müdürü İsmail Canbulad Bey'den Sivas Vilayeti'ne çekilen telgrafta bayrağı indirene ne yapıldığı ve bayrağın iade edilip edilmediği hakkında bilgi verilmesi istenmiştir (BOA, DH.ŞFR, 48/249). Bir gün sonra (3 Ocak 1915) Sivas Valisi Ahmed Muammer Bey'den Dahiliye Nezareti'ne çekilen telgrafta kapitülasyonların kaldırıldığı haberiyle sevinçle yapılan gösteri sırasında esnaftan Hocazade Şükrü Efendi adlı bir kişinin Singer mağazasındaki Amerika bayrağını indirerek polis idaresine teslim ettiği ve bayrağın halen polis idaresinde olduğu bildirilmiştir. Yine bu telgraftan hadisenin sadece bundan ibaret olduğu halde durumu farklı bir şekilde Amerika Sefareti'ne bildiren kişinin ise Fransa konsolosluğu tercümanı Manuk olduğunun anlaşıldığı bilgisi kayıtlıdır (BOA, DH.ŞFR, 456/61). Ertesi gün (4 Ocak 1915) Dahiliye Nazırı Mehmed Talat Bey meseleye dahil olarak Sivas Vilayeti'ne Singer mağazasından alınan Amerika bayrağının iade edilmesi ve bundan sonra tarafsız devletlere karşı bu gibi davranışlara izin verilmemesi gerektiği talimatını vermiştir (BOA, DH.ŞFR, 49/271).

Bu yazışmalardan sonra Osmanlı Devleti konuyu takip etmiştir. Yaklaşık bir buçuk ay sonra 16 Şubat 1915 tarihli ve Dahiliye Nazırı namına Emniyet-i Umumiye Müdürü İsmail Canbulad Bey'den Sivas Vilayeti'ne çekilen telgrafta Amerika bayrağının sahibine iade edilip edilmediğinin bildirilmesi istenmiştir (BOA, DH.ŞFR, 50/17). 17 Şubat 1915 tarihli ve 
Sivas Valisi Ahmed Muammer Bey'den Dahiliye Nezareti'ne çekilen cevabî telgrafta bayrağın sahibine iade edildiği bildirilmiştir (BOA, DH.ŞFR, 461/92).

Olay aslında büyütülecek bir mesele değildir ama asırlardır Osmanlı Devleti sayesinde zenginliğine zenginlik katan devletlerden olan Fransa'nın bir görevlisinin meseleyi abartması, krizi fırsata çevir(ebil)me adına çabasıdır. Kapitülasyonların kaldırılmasına sevinen bir Türk'ün o haletiruhiye ile yabancı devletlerden birinin bayrağını alıp polise teslim etmesi anlaşılabilecek bir hadisedir. Fakat burada iki nokta önemlidir. Her ne kadar bir Türk esnafın devletinin ayağına pranga, sırtına kambur olan kapitülasyonun kaldırıması sevinciyle taşkınlık yapması normal sayılabilirse de indirdiği ve polise teslim ettiği bayrak Amerika bayrağıdır. Amerika bu süreçte tarafsız devletlerdendir. Diğer husus ise bu bayrak indirme olayını büyüten Fransız'dır. Hangi niyetle yaptığı tam olarak bilinemese de ve konuyla alakalı olarak bir ifadesine belgelerde rastlanılmamışsa da Osmanlı Devleti'ni uluslararası kamuoyunda zor durumda bırakmaya çalıştığı aşikardır.

\section{SONUÇ}

Tarihteki bazı terimler gerçekten tarih olmuştur fakat bazı terimler tarihin gerçek anlamına uygun olarak günümüzde de etkisini hissettirir. Kapitülasyon kelimesi de bu minvaldedir. Tarih başta olmak üzere sosyal bilimlerdeki bazı alanların kitaplarındaki kapitülasyon kavramı günümüzde de yaşamaktadır. Kapitülasyonun modern dünyadaki faydalanan devletlerinin bir kısmı yeni olsa da önemli bir kısmı birkaç asır önceki devletlerdir. Karakterlerinin gereği olarak bazı devletlerdeki yerli vatandaşlardan daha çok hakka sahiptirler.

Kapitülasyon kelimesi için farklı tanımlamalar yapılsa da kavram olarak bir devlettin kendi vatandaşlarının zararına olacak hakları başka ve doğru bir tabirle ayrıcalıkları yabancılara tanımasıdır. Osmanlı Devleti, kapitülasyonlar yerine Tanzimat dönemine kadar ahidnâme, imtiyâzât" ya da "uhûd-i atîka" tabirlerini kullanmıştır. Osmanlı Devleti kapitülasyonları ilk verdiği zaman döneminin en güçlü devletinden biriydi. Avrupalı devletlere verdiği ayrıcalık Osmanlı Devleti'ne 1500'lü yıllarda zarar verdi denilemez. Fakat sonraki tarihlerde iş değişmiştir. Avrupalı devletlerin Osmanlı Devleti'nde sürekli ya da geçici olarak bulunan vatandaşlarının elde ettikleri ayrıcalıklar, ticaret ve gümrük konularında elde ettikleri kolaylıklar hangi kelime ile ifade edilirse edilsin devletin haliyle de Osmanlı halkının zararınadır. 
Osmanlı Devleti, gücünün zirvesindeyken Avrupalı devletlere tanıdığı ayrıcalıkların ekonomisi başta olmak üzere nerdeyse her yapısına aşikâr bir şekilde zarar verince bunları bertaraf etmek istedi. Kısacası 1500'lü yıllarda başlayan bu ayrıcalıklar iki asır geçmeden Osmanlı Devleti'nin başına bela olmuştur. Öyle ki Tanzimat döneminde Osmanlı Devleti'ndeki yabancılar her şeye karışır olmuşlar, kendileriyle alakası olmayan meselelere bile yerine göre müdahil olmuşlardır. Avrupalı devletlerin Osmanlı'daki elçilik görevlileri bazen sadrazamlara karşı oldukça hakaretamiz davranmışlardır. Osmanlı Devleti'ni sömürge gibi gören ayrıcalıklı kişiler olağanüstü zenginlik elde etmişlerdir.

19. yüzyılın ikinci yarısından itibaren kapitülasyonları kaldırma girişimlerinde bulunan Osmanlı Devleti her defasında başarısız olmuştur. Ayrıcalıklardan faydalananlar Osmanlı Devleti'nin bu girişimlerinden etkilenmediği gibi adeta her girişim sonrasında daha fazlasını kazanmıştır. 20. Yüzyılın ilk çeyreğinin muktediri olan İttihat ve Terakki, Osmanlı Devleti'nin asırlardır başına bela olan imtiyazları kaldırmak için zaman kollamıştır. Birinci Dünya Savaşı'nın başlamasına kısa bir süre kala bloklaşan Avrupalı devletlerin birbirlerine karşı cephe almasını fırsat bilen İttihat ve Terakki Hükümeti gerekli mevzuatı yerine getirdikten sonra dönemi padişahı Sultan Mehmed Reşad'ın 8 Eylül 1914 tarihli iradesiyle tek taraflı olarak kapitülasyonların kaldırıldığını ilan ettirdi. 1 Ekim 1914 tarihinden itibaren artık ayrıcalıkların olmayacağı hususunda Avrupalı devletlere nota verildi. Kapitülasyonların kaldırılması tahmin edileceği gibi epeyce yankı bulmuştur. Bazı devletler bu karardan tedirgin olmuştur.

Kapitülasyonların kaldırılması kararının ardından Osmanlı'da herkes çok sevinçlidir. Halkın bu sevinci gazetelere yansımıştır. Avrupalı devletlere verilen ayrıcalıkların kaldırılmasıyla yeni bir döneme geçildiği, bu kararın bir milat olduğu düşünülmüştü. İstanbul başta olmak üzere şehirlerin pek çoğunda sevinçli etkinlikler düzenlemiştir. Hata bu özel günün millî bayram olarak ilan edilmesi talep edilmiştir. Hükümete (İttihat ve Terakki) yüzlerce tebrik telgrafı gelmiştir. Fakat bir yıl sonra, kapitülasyonların kaldırılmasının yıl dönümünde şaşırtıcı bir şekilde neredeyse unutulmuştur.

Birinci Dünya Savaşı'ndan yenik ayrılan Osmanlı Devleti 1918 sonrasından Lozan'a kadar 1914'e kadar uygulanan kapitülasyonların daha fazlasını yaşamak zorunda kalmıştır. Kapitülasyonların tamamen kaldırılması Lozan Barış Antlaşması ile mümkün olmuştur. 


\section{KAYNAKÇA}

\section{Arşiv Kaynakları}

Türkiye Cumhuriyeti Devlet Arşivleri Başkanlığı Osmanlı Arşivi (BOA)

Dahiliye Şifre Kalemi (DH. ŞFR)

440 / 67, 44 / 239, 48 / 249, 456 / 61, 49 / 271, 50 / 17, 461 / 92

Bâb-ı Ali Evrak Odası (BEO)

4309 / 323145 - 40, 4309 / 323145 - 54, 4309 / $323145-23,4309$ /

323145 - 44, 4309 / 323145 - 55, 4309 / 323145 - 60-1-9

İrade Meclis-i Mahsus (İ.MMS)

$188 / 22-5$

\section{Yayımlanmış Arşiv Belgeleri}

Başbakanlık Devlet Arşivleri Genel Müdürlüğü (2013). Osmanlı Belgelerinde Birinci Dünya Harbi. (Haz.). Komisyon, Osmanlı Arşivi Daire Başkanlığı.

Rus Dışişleri Gizli Arşivinin Gizli Belgelerinde Osmanlı'nın Cihan Harbine Girişi (2018). (Çev. ve Haz.). Azad Ağaoğlu. İstanbul: Ötüken Neşriyat.

\section{Resmi Yayınlar}

Düstur

\section{Süreli Yayınlar*}

İkdam

Takvim-i Vekayi

\section{Telif Eserler}

Aker, E. Z. (1999). Tanzimat Dönemi Osmanlı Sanayileşme Sorunları ve Kapitülasyonlar. (Yüksek Lisans Tezi). YÖK Ulusal Tez Merkezi. 81950.

Alkan, N. (2020). İmparatorluğun Son Savaşı. İstanbul: Timaş Yayınları.

Arslan, O. (2008). Birinci Dünya Savaşı Başında Kapitülasyonların İttihat Terakki Tarafından Kaldırılması ve Bu Gelişmeler Karşısında Büyük Güçlerin Tepkileri. Sakarya Üniversitesi Fen-Edebiyat Fakültesi Dergisi 10(1), 261278.

Atatürk. M. K. (1927). Nutuk. Ankara.

Cevizliler, E. \& Akbulut, S. (2019). Lozan Barış Konferansı'nda Kapitülasyonlar Meselesi ve İsmet Paşa. Atatürk Dergisi 8(2), 161-193.

\footnotetext{
${ }^{*}$ Künyeler metin içerisinde gösterilmiştir.
} 
Cudi, O. (1331/1915). Kapitülasyonlar Nasıl Kalkar? (Bir Japon Mualliminin Fikri). İslâm Dünyası 12, 180-182.

Elmacl, M. E. (2001). II. Meşrutiyetten Lozan'a Kapitülasyonlar. (Doktora Tezi). YÖK Ulusal Tez Merkezi. 103859.

Eşref, E. (1330/1914). Kapitülasyonların İlgası. Sebilürreşad 12(310), 417417.

İnalcık, H. (2000). İmtiyazât. TDV İslam Ansiklopedisi Cilt: 22, (s. 245252). İstanbul: Türk Diyanet Vakfı Yayınları.

Kallek, C. (2000). İmtiyazât. TDV İslam Ansiklopedisi Cilt: 22, (s. 242-245). İstanbul: Türk Diyanet Vakfı Yayınları.

Karabulut, S. (2018). Savaş Yılları Osmanlı Kudüs'ünde Mülkiyet Hakkı (1914-1918). Tarih İncelemeleri Dergisi 33(2), 451-480.

Külünk, M. E. (2006). Kapitülasyonların Kaldırılması (1914). (Yüksek Lisans Tezi). YÖK Ulusal Tez Merkezi. 209827.

Pamir, A. (2002). Kapitülasyon Kavramı ve Osmanlı Devleti'ne Etkileri. AÜHFD 51/2, 79-119.

Reşid, A. (1928). Kapitülasyonlar. Darülfünun Hukuk Fakültesi Mecmuası 6(37), 1-38.

Salem, R. (1926). Hukuk-ı Beynelmilel: Türkiye'de Kapitülasyonların İ̀ga Edildiği Tarihin Tespiti. Hukukî Bilgiler Mecmuası 1(2), 81-85.

Sanders, L. V. (1999). Türkiye'de Beş Yıl C: 2. İstanbul: Cumhuriyet Gazetesi Yayınları.

Semiz, Y. \& Yusuf, K. (2019). Birinci Dünya Savaşı Yıllarında Millî İktisat Fikrinin Gelişimi ve İtibar-ı Millî Bankası. International Social Sciences Studies Journal 5(39), 3803-3812.

Yerlikaya, A. (2011). Osmanlı Devleti ve Kapitülasyonlar. (Yüksek Lisans Tezi). YÖK Ulusal Tez Merkezi. 289481. 


\section{EKLER}

Mebus Hüseyin Cahit Bey, kapitülasyonların kaldırılma gününün İd-i Millî (Millî Bayram) olarak kutlanması için alınan kararı Sadrazama sunarken. (İkdam, 12 Eylül 1914).

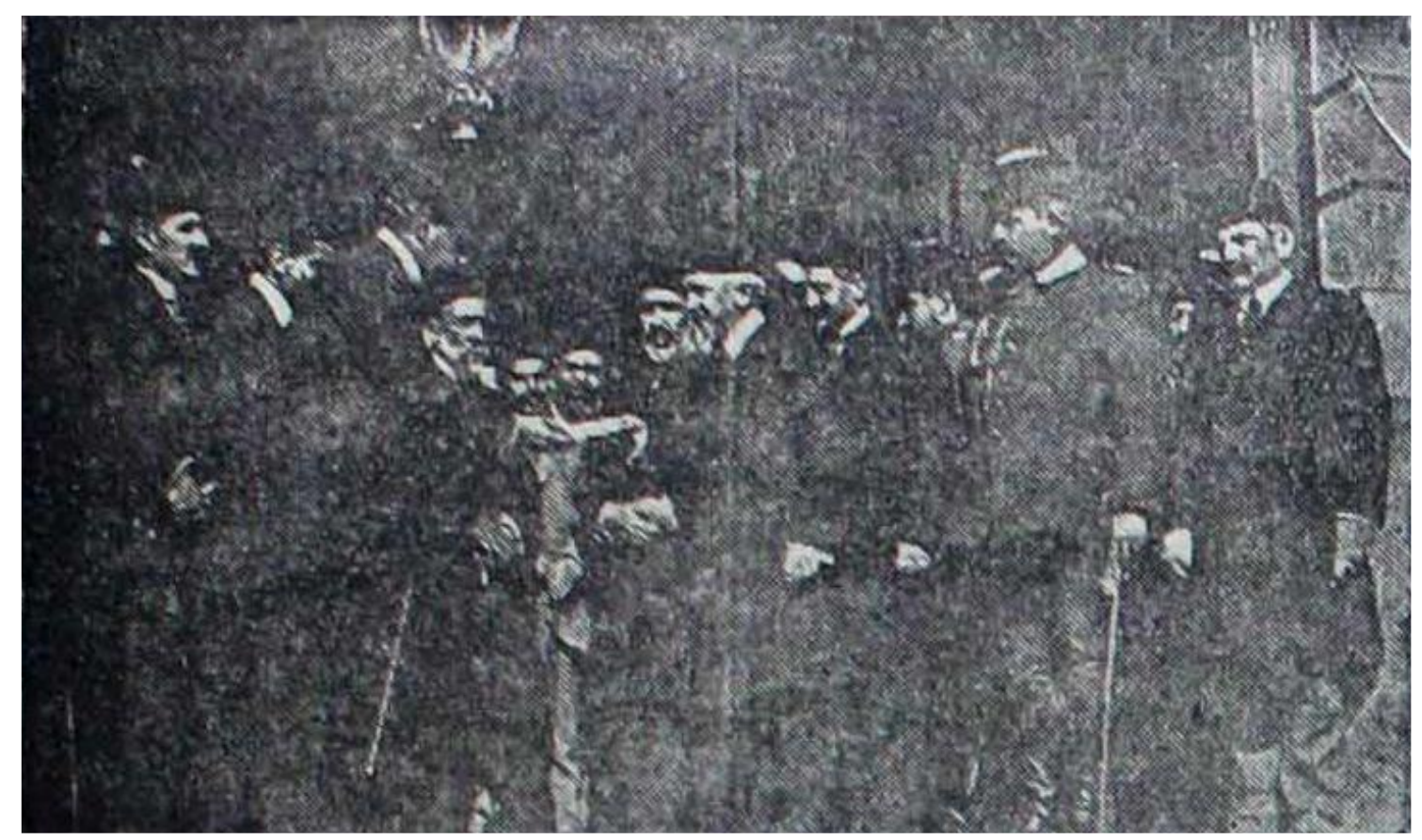

(Ek1)

Kapitülasyonlarından kaldırılmasından sonra İstanbul'daki gösterilerden bir karede Müdafa-i Millîye ve Muavenet-i Millîye Cemiyetleri görülüyor. (İkdam, 13 Eylül 1914). 


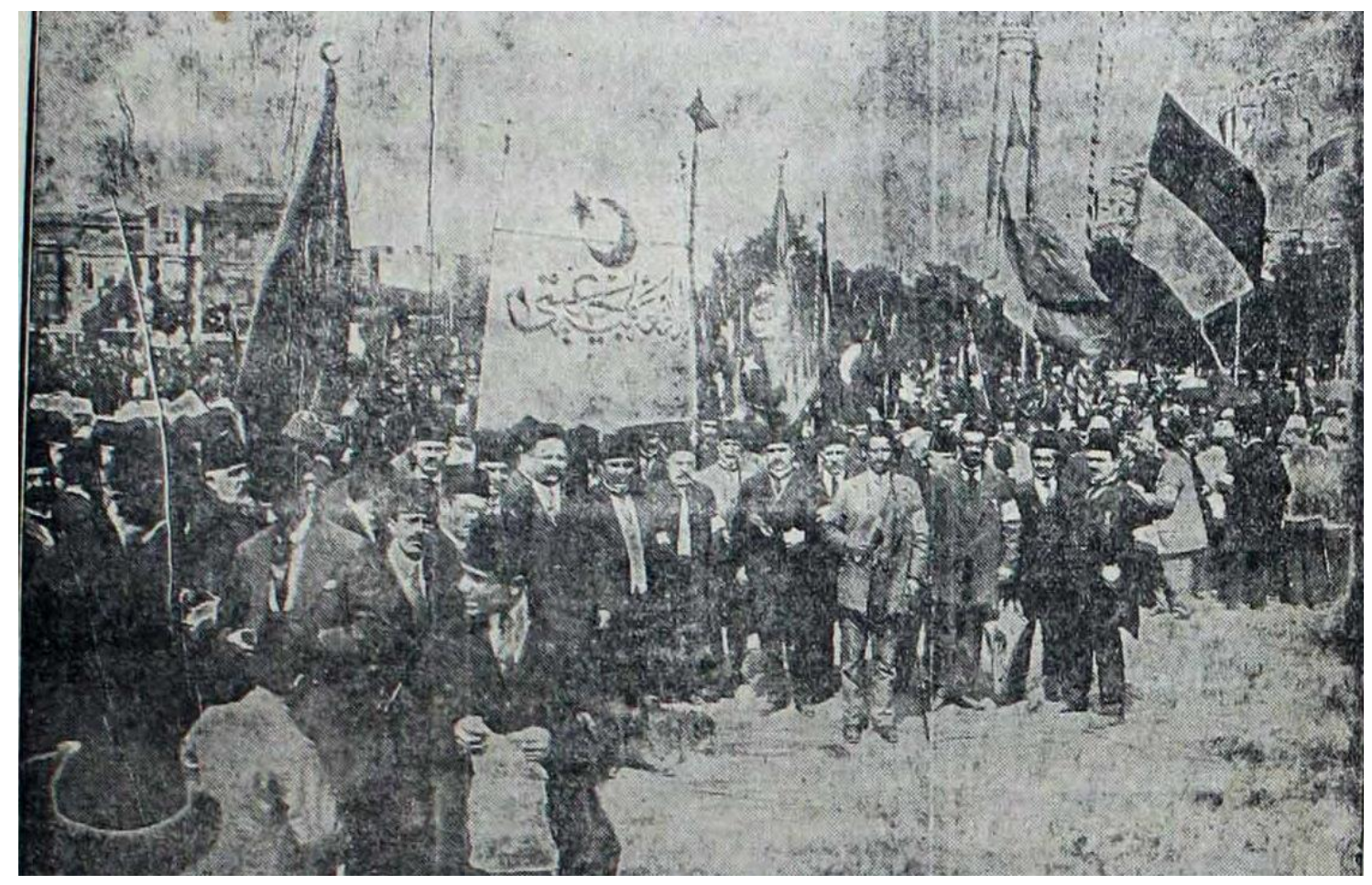

(Ek2)

GENIŞ̧ETÍLMİŞ ÖZET: Osmanlı Devleti'nde Kapitülasyonların Kaldırıması Sonrasında Halkın Tepkilerine Dâir Bazı Tespitler başlıklı çalışması bir asırdan önceki hadiseyi anlatmaya odaklanırken dünya tarihinde birçok devletin kapitülasyonlarla tanışıklığını daha net fark etmiştir. Kapitülasyonlardan kaynaklı olarak hem uzun süre hem de gayet belirgin bir şekilde zarar gören devletlerin başında Osmanlı Devleti geliyor denilse mübalağa edilmiş olmaz. Osmanlı Devleti, kapitülasyonlar yerine Tanzimat dönemine kadar ahidnâme, imtiyâzât" ya da "uhûd-i atîka" tabirlerini kullanmıştır. Kapitülasyon kelimesi için farklı tanımlamalar yapılsa da kavram olarak bir devlettin kendi vatandaşlarının zararına olacak hakları başka ve doğru bir tabirle ayrıcalıkları yabancılara tanımasıdır. Kapitülasyon kelimesinin anlamı Osmanlı Devleti için her dönem aynı olmamıştır. 1500'lü yıllarda, yani Osmanlı Devleti kapitülasyonları ilk verdiği dönemde asrının en güçlü devletinden biriydi. Dış politikayla bağlantılı olarak Avrupalı devletlere Osmanlı Devleti'nin bir tercihiyle verilen kapitülasyonların o yıllarda devlete zarar verdiği düşünülmemektedir. Daha sonraki asırlarda Osmanlı Devleti'nin siyasi ve ekonomik gücü Avrupalı devletler karşısında neredeyse devamlı olarak gerilemiştir. 1500 'lü yıllarda Avrupalı devletlerin sürekli ya da geçici olarak bulunan vatandaşlarının elde ettikleri ayrıcalıklar, ticaret ve gümrük konularında elde ettikleri kolaylıklar Osmanlı Devleti'ne önemli külfetler getirmiştir. Avrupalı devletlere tanınmış olan ayrıcalıkların Osmanlı Devleti'nin ekonomisi başta olmak üzere nerdeyse her yapısına gayet belirgin bir şekilde hissedildikten sonra bunun bertaraf edilmesi için çalışmıştır. 19. yüzyıla gelinceye kadar bazı hamleler yapsa da başarılı olamayan Osmanlı Devleti'nin yöneticileri özellikle bu yüzyılda 
kapitülasyonların kaldırılmasının aciliyetini daha net olarak fark etmişlerdir. Çünkü bu kapitülasyonların tanıdığı ayrıcalıklara güvenen yabancılar her şeye müdahale edebilmekteydiler. Hatta Avrupalı devletlerin Osmanlı'daki elçilik görevlileri korkusuzca davranma cüretini göstermişlerdir. Yeri geldiğinde sadrazamlara karşı tahkir edici söz ve davranışlarda bulunmuşlardır. Osmanlı Devleti'ni sömürge gibi gören ayrıcalıklı kişiler olağanüstü zenginlik elde etmişlerdir. Fakat, Osmanlı Devleti'nin verdiği bu ayrıcalıklar sadece ekonomik yönlerden problem teşkil etmemektedir. Aynı zamanda devletin bağımsız yapısı da zedelenmiştir. Bunu fark eden Osmanlı Devleti yöneticilerinin farklı çareler düşündüğü belgelere yansımıştır. Kapitülasyonlardan kurtulmak isteyen Osmanlı Devleti'nin her girişimi sonrasında kurtulamadığı gibi neredeyse her defasında mağduriyeti daha da artmıştır. Osmanlı Devleti'nin son iki asrında askeri yönden Avrupalı devletlerin epeyce gerisinde kaldığı yapılan savaşların neticesinden anlaşılmaktadır. Başta Rusya olmak üzere savaşılan devletlere karşı kaybeden Osmanlı Devleti'nin ekonomik gücü de doğru orantılı olarak olumsuz etkilenmiştir. Gittikçe zayıflayan Osmanlı Devleti'nin kapitülasyonları kaldırabilme gücü ve yeteneği de mümkün olmamıştır. 1877-78 yılında meydana gelen Osmanlı-Rus Savaşı'ndan sonra daha da zor durumda kalan Osmanlı Devleti'nin denge politikasıyla hayatta kalmaya çalıştığı yıllarda Avrupalı devletler daha da zenginleşebilmenin gayretindedir. Bir taraf (Osmanlı Devleti) zayıflarken diğer taraf (kapitülasyon verilen devletler) güçlenmiştir. Bu denklemde elbette kapitülasyonların kaldırılabilmesi hayal olmuştur. Avrupalı devletler İttifak ve İtilaf olarak iki blokta ayrı düşerken Birinci Dünya Savaşı da yaklaşmıştır. 20. Yüzyılın ilk çeyreğinde Osmanlı Devleti'nde önemli değişiklikler meydana gelmiştir. 1876 'da kapatılan Meclis-i Mebusan yeniden açılarak Meşrutiyet aktifleşmiştir. II. Meşrutiyet olarak anılan süreç 1908 'de başladıktan sonra seçimler yapılmıştır. İttihat ve Terakki Cemiyeti II. Meşrutiyet'in ilanında oldukça önemli bir noktadadır ve 1913'teki Babıali Baskını sonrasında gerçek muktedir olmuşlardır. Avrupalı devletlerin büyük bir savaşa tutuşacağını gören ve bu çarpışmada ayakta kalmak isteyen Osmanlı Devleti kararsız kalmıştır. Almanya ile zaten yakın temasta olan Osmanlı Devleti yöneticileri Fransa, İngiltere ve Rusya ile görüşmeler yapmışsa da netice elde edememiştir. 1914'te Avrupa'da patlak veren Birinci Dünya Savaşı'ndan hemen sonra yaşanan gelişmelere bakıldığında Osmanlı Devleti'nin hangi blokta yer alacağı halen netleşmemiştir. Aynı zamanda kapitülasyonların kaldırılabilmesi de Osmanlı Devleti'nin argümanları arasında yer almıştır. Avrupalı devletlerin birbirlerine karşı cephe almasını fırsat bilen İttihat ve Terakki Hükümeti gerekli mevzuatı yerine getirdikten sonra dönemin padişahı Sultan Mehmed Reşad'ın 8 Eylül 1914 tarihli iradesiyle tek taraflı olarak kapitülasyonların kaldırılığını ilan ettirmiştir. 1 Ekim 1914 tarihinden itibaren artık ayrıcalıkların olmayacağı hususunda Avrupalı devletlere nota verilmiştir. Kapitülasyonların kaldırıması tahmin edileceği gibi epeyce yankı bulmuştur. Osmanlı Devleti'nin 2 Ağustos 1914'te gizli ittifak antlaşması yaptığı Almanlar diğer devletlerden daha çok itiraz etmiştir. Kapitülasyonların tek taraflı da olsa kaldırılması kararına Osmanlı Devleti'nin (özellikle Anadolu'da yaşayan halkın) çok sevindiği dönemin 
gazetelerine, belgelerine çok net şekilde yansımıştır. Osmanlı halkı yıllardır bir kambur gibi hissettikleri kapitülasyonların kaldırılması kararıyla çok mutlu olmuştur. Başkent İstanbul başta olmak üzere ülkenin önemli bir kısmında özellikle de Anadolu'da kapitülasyonların kaldırılması büyük sevinçlerle karşılanmıştır. Gösteriler düzenlenmiştir. Kapitülasyonların kaldırımasının milli bayramlar gibi kutlanması bile gündeme gelmiştir. Gerçi daha ilk yıldönümünde bile kapitülasyonların kaldırılmasını neredeyse hatırlayan olmamıştır ama 1914 yılında kapitülasyonların tek taraflı da olsa kaldırılması yıllardır acısını en derinden hisseden Osmanlı halkını oldukça mutlu etmiştir. Kapitülasyonların kaldırılması kararının ardından halkın sevinci gazetelere yansımıştır. Avrupalı devletlere verilen ayrıcalıkların kaldırımasıyla yeni bir döneme geçildiği, bu kararın bir milat olduğu düşünülmüştür. İstanbul başta olmak üzere şehirlerin pek çoğunda sevinçli etkinlikler düzenlemiştir. Hata bu özel günün millî bayram olarak ilan edilmesi talep edilmiştir. Hükümete (İttihat ve Terakki) yüzlerce tebrik telgrafı gelmiştir. Fakat bir yıl sonra, kapitülasyonların kaldırılmasının yıl dönümünde şaşırtıcı bir şekilde neredeyse unutulmuştur. Birinci Dünya Savaşı'ndan yenik ayrılan Osmanlı Devleti 1918 sonrasından Lozan'a kadar 1914'e kadar uygulanan kapitülasyonların daha fazlasını yaşamak zorunda kalmıştır. Kapitülasyonların tamamen kaldırılması Lozan Barış Antlaşması ile mümkün olmuştur.

EXTENDED ABSTRACT: His work, titled some determinations on the reactions of the people after the abolition of capitulations in the Ottoman state, focused on describing the event more than a century ago, while he more clearly noticed the familiarity of many states with capitulations in the history of the world. As a result of capitulations, the Ottoman State is coming at the beginning of the states that have suffered both for a long time and very clearly. The Ottoman Empire used the terms ahidname, concession" or "uhud-i atika" until the Tanzimat period instead of capitulations. Although different definitions are made for the word capitulation, the concept is that a state recognizes privileges to foreigners, in other and correct terms, rights that will be to the detriment of its citizens. The meaning of the word capitulation was not always the same for the Ottoman State. In the 1500s, that is, the Ottoman State was one of the most powerful states of its century when it first gave capitulations. Capitulations given to European states in connection with foreign policy by the choice of the Ottoman state are not considered to have harmed the state in those years. In the following centuries, the political and economic power of the Ottoman Empire almost steadily declined in the face of European states. In the 1500 s, the privileges obtained by the citizens of European states who were permanently or temporarily, and the amenities obtained in trade and customs issues brought significant burdens to the Ottoman State. After the privileges granted to European states were clearly felt in almost every structure of the Ottoman state, especially in the economy, he worked to eliminate it. 19. despite making some moves before the century, the rulers of the Ottoman State, who did not succeed, realized more clearly the urgency of removing the capitulations, especially in this century. Because foreigners who relied on the 
privileges recognized by these capitulations could interfere with everything. Even the embassy officials of European states in the Ottoman Empire dared to act fearlessly. When it came, they made insulting words and behaviors against the grand viziers. Privileged people who considered the Ottoman state as a colony achieved extraordinary wealth. But these privileges granted by the Ottoman state are not only a problem in economic aspects. At the same time, the independent structure of the state has also been damaged. It was reflected in the documents that the rulers of the Ottoman State, who realized this, considered different remedies. After every attempt by the Ottoman State, which wanted to get rid of the capitulations, it could not get rid of it, and almost every time its victimization increased. It is understood from the result of the wars that the Ottoman Empire fell far behind the European states militarily in the last two centuries. The economic power of the Ottoman Empire, which lost against the warring states, especially Russia, was also negatively affected in direct proportion. The power and ability of the increasingly weakened Ottoman state to remove the capitulations was also not possible. In the years when the Ottoman State, which was in an even more difficult situation after the Ottoman-Russian war that occurred in 1877-78, tried to survive with its balance policy, European states were striving to become even richer. One side (the Ottoman State) was weakened, while the other side (the capitulated States) was strengthened. In this equation, of course, it has been a dream that capitulations can be removed. As European states fell apart in the two blocs as an alliance and Entente, the First World War was also approaching. 20. In the first quarter of the century, significant changes occurred in the Ottoman Empire. Parliament-i Mebusan, which was closed in 1876, was reopened and legitimacy became active. II. Elections were held after the process called legitimacy began in 1908. Union and Progress Society II. They are at a very important point in the declaration of legitimacy and became real capable after the Babiali raid in 1913. The Ottoman State, which saw that European states would engage in a great war and wanted to survive this conflict, remained undecided. Although the rulers of the Ottoman State, who were already in close contact with Germany, held talks with France, Britain and Russia, they did not get a result. Looking at the developments immediately after the First World War, which broke out in Europe in 1914, it is still unclear which block the Ottoman State will take part in. At the same time, the abolition of capitulations was one of the arguments of the Ottoman State. After the Government of Union and progress, which knew the opportunity for European states to turn against each other, fulfilled the necessary legislation, the Sultan of the period, Sultan Mehmed Reşad, unilaterally declared the abolition of capitulations by the will of 8 September 1914 . From 1 October 1914 , a note was given to European states that there would no longer be privileges. The removal of the capitulations has, predictably, had quite a few repercussions. The Germans, with whom the Ottoman State made a secret alliance treaty on August 2, 1914, objected more than any other state. The decision to abolish the capitulations, albeit unilaterally, was reflected very clearly in the newspapers and documents of the 
period when the Ottoman state (especially the people living in Anatolia) was very happy. For years, the Ottoman people were very happy with the decision to remove the capitulations, which they felt like a hump. The abolition of capitulations was welcomed with great joy in a significant part of the country, especially in the capital Istanbul, especially in Anatolia. Demonstrations were organized. The abolition of capitulations has even been celebrated as national holidays. Although, even on the first anniversary, no one almost remembered the abolition of the capitulations, but the unilateral abolition of the capitulations in 1914 made the Ottoman people, who felt their pain most deeply for many years, very happy. After the decision to abolish the capitulations, public joy was reflected in the newspapers. It was believed that a new era was passed with the abolition of privileges granted to European states, this decision was a milat. He organized joyful events in many cities, especially Istanbul. Hata requested that this special day be declared as a national holiday. Hundreds of congratulatory telegrams have come to the government (Union and progress). But a year later, on the anniversary of the removal of the capitulations, it was surprisingly almost forgotten. The Ottoman State, which succumbed to the first World War, had to experience more of the capitulations applied from 1918 to Lausanne until 1914. The complete abolition of the capitulations was made possible by the Lausanne peace treaty. 